\title{
PENGARUH STRATEGI PEMASARAN TERHADAP KEPUASAN NASABAH BANK SYARIAH PADA BANK SYARIAH MANDIRI CABANG PALOPO
}

\author{
Nur rizka farhana \\ nurizkafarhana@gmail.com
}

\begin{abstract}
This study discusses the Effect of Marketing Strategy on Customer Satisfaction of Islamic Banks at Bank Syariah Mandiri Palopo Branch. The focus of the discussion is located on the influence of marketing strategies and customer satisfaction at the Palopo branch of the Syariah Mandiri Bank. In this study using field research, by directly examining the object, namely the customers of Bank Syariah Mandiri, Palopo branch. This study uses a quantitative research type, the population in this study is the customers of Bank Syariah Mandiri Palopo branch totaling 3600 people, with a sample of 50 people who were given a questionnaire. The technique used in sampling is a technique (probability sampling) of simple random sampling (random sample). The instrument used is a questionnaire with 23 statement items presented in the form of a Likert scale. Based on the results of the research that has been done, it can be seen that the marketing strategy implemented at the Palopo Branch of the Syariah Mandiri Bank has a positive and significant impact on customer satisfaction with value. obtained by the value of $\mathrm{t}(3,432)$ is greater than the value of $\mathrm{t}$ table $(1,660)$. The magnitude of the influence of the marketing strategy on customer satisfaction at Bank Syariah Mandiri Palopo Branch 0.895. Customer satisfaction at Bank Syariah Mandiri before the increase in marketing strategy was 36,639 when the marketing strategy was increased by 1 point, the satisfaction increased by 0.895 .

Keywords: Marketing Strategy, Customer Satisfaction.
\end{abstract}

\begin{abstract}
ABSTRAK
Penelitian ini membahas mengenai Pengaruh Strategi Pemasaran Terhadap
\end{abstract} Kepuasan Nasabah Bank Syariah pada Bank Syariah Mandiri Cabang Palopo. Fokus kajian pembahasan yaitu terletak pada pengaruh strategi pemasaran dan kepuasan nasabah di Bank Syariah Mandiri Cabang Palopo.Dalam penelitian ini menggunakan penelitian

\footnotetext{
${ }^{1}$ Muhammad, Manajemen Bank Syariah, (Yogyakarta: UUP AMPYEK, 2002), h. 13.
} 
lapangan, dengan meneliti langsung pada objek, yaitu nasabah Bank Syariah Mandiri cabang Palopo. Penelitian ini menggunakan jenis penelitian kuantitatif, populasi dalam penelitian ini adalah nasabah Bank Syariah Mandiri cabang Palopo berjumlah 3600 orang, dengan penarikan sampel 50 orang yang diberikan angket. Tehnik yang digunakan dalam pengambilan sampel adalah tehnik (probability sampling) pengambilan sampel acak sederhana (random sample). Instrumen yang digunakan adalah angket (kuesioner) dengan 23 butir pernyataan yang disajikan dalam bentuk skala likert.Berdasarkan hasil penelitian yang telah dilakukan maka dapat diketahui bahwa strategi pemasaran yang diterapkan di Bank Syariah Mandiri Cabang Palopo mempunyai pengaruh yang positif dan signifikan terhadap kepuasan nasabah dengan nilai yang diperoleh nilai thitung $(3,432)$ lebih besar dari nilai tabel $(1,660)$. Besar pengaruh yang ditimbulkan strategi pemasaran terhadap kepuasan nasabah di Bank Syariah Mandiri Cabang Palopo 0,895. Kepuasan nasabah pada Bank Syariah Mandiri sebelum adanya peningkatan strategi pemasaran adalah sebesar 36,639 ketika strategi pemasaran ditingkatkan 1 poin maka kepuasan bertambah 0,895.

\section{Kata Kunci : Strategi Pemasaran, Kepuasan Nasabah.}

\section{PENDAHULUAN}

\section{A. Latar Belakang Masalah}

Perbankan syariah dalam peristilahan internasional dikenal sebagai Islamic Banking atau juga disebut dengan Interest-fee Banking. Peristilahan dengan menggunakan kata Islamic tidak dapat dilepaskan dari asal-usul sistem perbankan syaria'ah itu sendiri. Bank syariah dikembangkan pada awalnya sebagai suatu respon dari kelompok ekonomi dan praktisi perbankan muslim yang berupaya mengakomodasi desakan dari berbagai pihak yang menginginkan agar tersedia jasa transaksi jasa keuangan yang dilaksanakan sejalan dengan nilai moral dan prinsip-prinsip syariah Islam, utamanya berkaitan dengan praktek riba, kegiatan maisir (spekulasi), dan gharar (ketidak jelasan). ${ }^{1}$

Salah satu perusahaan yang bergerak di bidang jasa yaitu usaha jasa perbankan syariah dimana pada umumnya bank syariah memiliki tugas memberikan jasa melalui

\footnotetext{
${ }^{1}$ Muhammad, Manajemen Bank Syariah, (Yogyakarta: UUP AMPYEK, 2002), h. 13.
} 
penitipan uang (simpanan), peminjam uang (kredit) serta jasa-jasa keuangan lainnya. Oleh karena itu, bank harus dapat menjaga kepercayaan dari nasabahnya. Kepercayaan sangat penting, karena tanpa kepercayaan masyarakat, bank tidak akan berkembang. Untuk menjaga dan meningkatkan kepercayaan nasabahnya maka bank perlu menjaga positif di mata ma syarakatnya. Tanpa citra positif maka kepercayaan yang sedang dan akan dibangun tidak akan efektif. Untuk meningkatkan citra perbankkan maka bank perlu menyiapkan karyawan yang mampu memberikan kepuasan nasabah, melalui pelayanan yang dapat memenuhi keinginan dan kebutuhan. ${ }^{2}$

Dengan adanya bisnis perbankan syariah di Palopo, masyarakat memiliki lebih banyak pilihan dalam mengelola dananya. Bank syariah menawarkan begitu banyak produk layanan yang sangat memanjakan para nasabahnya. Kondisi persaingan bisnis perbankan ini mendorong setiap bankir untuk mencari berbagai strategi pelayanan terbaik agar dapat menarik nasabah baru dan mempertahankan nasabah yang telah ada.

Berdasarkan uraian di atas, maka penulis bermaksud untuk mengetahui dan mempelajari tentang strategi pemasaran yang dilakukan oleh Bank Syariah Mandiri kota Palopo sehingga penulis mengambil sebuah judul "Strategi Pemasaran Terhadap Kepuasan Nasabah Bank Syariah Mandiri Cabang Palopo”.

\section{B. Rumusan Masalah}

Berdasarkan uraian latar belakang diatas, maka penulis mengemukakan rumusan masalah, antara lain:

1. Bagaimana pengaruh strategi pemasaran terhadap kepuasan nasabah di Bank Syariah Mandiri Cabang Palopo?

2. Berapa besar pengaruh yang ditimbulkan strategi pemasaran terhadap kepuasan nasabah di Bank Syariah Mandiri Cabang Palopo?

\section{C. . Defenisi Operasional}

Dalam poin ini akan dijelaskan yang dimaksud variabel-variabel yang digunakan dalam penelitian ini sebagai berikut:

1. Strategi pemasaran

Suatu rencana atau rancangan keseluruhan untuk mencapai sebuah tujuan dan keuntungan. Strategi ini dilakukan dengan cara melihat apa yang dibutuhkan oleh para konsumen atau pelanggan.

2. Pemasaran

\footnotetext{
${ }^{2}$ Kasmir , Pemasaran BANK, (Cet. I; Jakarta: Kencana, 2004), h. 201.
} 
Merupakan suatu proses yang dilakukan oleh para pedagang atau perusahaan dalam mempromosikan barang jualannya kepada para pembeli.

3. Kepuasan nasabah

Perasaan seorang nasabah yang didorong atau menjadi representasi kesesuaian harapan (terhadap layanan dan citra suatu produk) dengan substansi kinerja produk/jasa yang diterima.

4. Nasabah

Adalah seseorang atau suatu perusahaan yang mempunyai rekening koran atau deposito atau tabungan serupa lainnya pada sebuah bank

\section{KAJIAN PUSTAKA}

\section{A. Tinjauan Pustaka}

\section{Pemasaran dan Strategi Pemasaran}

Pemasaran merupakan suatu perencanaan, pelaksanaan, dan pengendalian dari kegiatan menghimpun dana, menyalurkan dana, dan jasa-jasa keuangan lainnya dalam rangka memenuhi kebutuhan, keinginan dan kepuasan nasabahnya. ${ }^{3}$ Sedangkan asosiasi pemasaran Amerika menawarkan defenisi formal Pemasaran adalah suatu fungsi organisasi dan seperangkat proses untuk menciptakan, mengkomunikasikan dan menyerahkan nilai kepada pelanggan dan mengelola hubungan pelanggan dengan cara yang menguntungkan organisasi dan para pemilik sahamnya". Saat berhadapan dengan proses pertukaran harus ada sejumlah besar pekerjaan dan keterampilan manajemen pemasaran terjadi bila sekurang-kurangnya satu pihak ada pertukaran potensial berfikir tentang makna mencapai tantangan yang diinginkan dari pihak lain. ${ }^{4}$

Dari beberapa pengertian tentang pemasaran dapatlah penulis simpulkan bahwa pemasaran sebagai suatu sistem dari kegiatan-kegiatan yang saling berhubungan, ditujukan untuk merencanakan, menentukan harga, mempromosikan dan mendistribusikan barang dan jasa pada kelompok pembeli merupakan proses dari kegiatan-kegiatan yang saling berhubungan antara satu dengan yang lain demi tercapainya suatu kebutuhan.

Pemasaran dan perdagangan memiliki keterkaitan yang erat antara satu dengan yang lain. Perdagangan dalam ilmu Ekonomi diartikan sebagai proses transaksi yang didasarkan atas kehendak sukarela dari masing-masing pihak. Dalam garis besarnya dapat

\footnotetext{
${ }^{3}$ Siti Asrifatul Husna, Strategi Pemasaran Produk Dana Dan Jasa Di Bank Syariah Mandiri (BSM) Cabang Salatiga, dalam (Skripsi: STAIN Salatiga, 2011), h. 31.

${ }^{4}$ Philip Kotler dan Kevin Lane Keller, Manajemen Pemasaran, op.cit., h. 6.
} 
dikatakan bahwa pemasaran adalah berbagai upaya yang dilakukan agar memudahkan terjadinya penjualan atau perdagangan.

Dalam dunia usaha strategi pemasaran merupakan suatu hal yang sangat diperlukan bagi seorang pengusaha dan pedagang. Strategi pemasaran merupakan suatu rencana keseluruhan untuk mencapai sebuah tujuan yang diinginkan oleh sebuah perusahaan.

Strategi pemasaran terdiri dari unsur-unsur pemasaran yang terpadu dan selalu berkembang, sejalan dengan gerak perusahaan dan perubahan-perubahan lingkungan pemasarannya serta perilaku konsumen. Tujuan perusahaan yang menganut konsep pemasaran adalah memberikan kepuasan kepada konsumen dan masyarakat lain dalam pertukarannya untuk mendapatkan laba. ${ }^{5}$

\section{Kepuasan Nasabah}

\section{a. Pengertian Kepuasan Nasabah}

Kepuasan nasabah, menurut Philip Kotler, adalah perasaan senang atau kecewa seseorang yang muncul setelah membandingkan kinerja produk yang dipikirkan terhadap kinerja yang diharapkan. ${ }^{6}$ Kepuasan nasabah dipengaruhi dua variabel utama, yaitu expectations (harapan) dan perceived performance (kinerja yang dirasakan). Bila perceived performance (kinerja yang dirasakan) melebihi expectations (harapan), maka konsumen mendapatkan kepuasan.

Islam mengajarkan bila ingin memberikan hasil usaha yang baik berupa barang maupun palayanan atau jasa hendaknya memeberikan yang berkualitas, jangan memberikan yang buruk atau tidak berkualitas kepada orang lain. Sebagaimana dijelaskan dalam Al-Qur'an QS Al-Baqarah ayat 267:

\footnotetext{
${ }^{5}$ Paulus Lilik Kristianto, Psikologi Pemasaran, (Cet I, Yogyakarta: CAPS, 2011), h. 28.

${ }^{6}$ Abdul Rahmat, Pengaruh Produk Gadai Emas Terhadap Kepuasan Nasabah di Bank Syariah Mandiri Cabang Pembantu Kota Palopo, dalam(Skripsi: Perpustakaan STAIN Palopo,2013), h. 45.
} 
Terjemahnya:

"Hai orang-orang yang beriman, nafkahkanlah (di jalan Allah) sebagian dari hasil usahamu yang baik-baik dan sebagian dari apa yang kami keluarkan dari bumi untuk kamu dan janganlah kamu memilih yang buruk-buruk lalu kamu nafkahkan darinya padahal kamu sendiri tidak mau mengambilnya melainkan dengan memicingkan mata terhadapnya. Dan ketahuilah bahwa Allah Maha Kaya lagi Maha Terpuji”.?

\section{b. Teknik Pengukuran kepuasan nasabah}

Metode-metode yang dapat dipergunakan setiap perusahaan untuk memantau dan mengukur kepuasan nasabah adalah sebgai berikut:

1) Sistem keluhan dan saran

Organisasi yang berwawasan pelanggan (customer oriented)akan membuat pelanggannya memberikan saran atau keluhan, misalnya dengan memberikan formulir bagi pelanggan untuk melaporkan kesukaan atau keluhan, penempatan kotak saran.

2) Pembeli bayangan (ghost shopping)

Antara lain untuk mengukur mengenai kepuasan pelanggan adalah dengan menyuruh orang berpura-pura menjadi pembeli dan melaporkan titik-titik kuat maupun lemah yang mereka alami sewaktu membeli produk perusahaan.

3) Analisa kehilangan pelanggan

Perusahaan seyogyanya menghubungi para pelanggan yang telah berhenti membeli atau yang telah pindah pemasok agar dapat memahami mengapa hal ini terjadi dan supaya dapat mengambil kebijakan perbaikan/penyempurnaan selanjutnya.

4) Survey pelanggan

Sebagian besar riset kepuasan pelanggan dilakukan dengan menggunakan metode survey, baik survey melalui pos, email, website maupun wawancara langsung. Melalui survey, perusahaan akan memperoleh tanggapan dan balikan secara langsung dari pelanggan dan juga me.mberikan kesan positif bahwa perusahaan menaruh perhatian terhadap para pelangganny. ${ }^{8}$

\section{c. Dimensi Kepuasan Nasabah}

1) Kehandalan:Yaitu kemampuan menyajikan kinerja layanan seperti yang dijanjikan dengan handal dan akurat.

\footnotetext{
${ }^{7}$ Menteri Agama RI, Al-Qur'an dan Terjemahannya, (Semarang: Asy-syifa', 2000), h. 35.

${ }^{8}$ Ahmad Khoiron, Pengaruh Kualitas Pelayanan Terhadap Kepuasan Nasabah Pada Bank Syariah Mandiri Cabang Malang, dalam (skripsi: UIN Maulana Malik Ibrahim Malang, 2010), h. 31.
} 
2) Daya tanggap:Kesediaan untuk membantu para pelanggan dan menyediakan layanan dengan cepat.

3) Empati:Merupakan bentuk kepedulian dan perhatian pribadi kepada nasabah.

4) Jaminan:Mencakup pengetahuan, kesopanan, dan kamampuan para staff untuk membangun kepercayaan pelaanggan.

5) Bukti fisik:Meliputi fasilitas, perlengkapan, tampilan fisik pegawai, serta sarana komunikasi.

\section{Bank Syariah}

\section{a. Pengertian Bank Syariah}

Kata Bank berasal dari bangue dalam bahasa Prancis dan dari banco bahasa Italia, yang berarti peti/lemari atau bangku. Kata peti atau lemari menyiratkan fungsi sebagai tempat menyimpan benda-benda berharga, seperti peti emas, peti berlian, peti uang dan sebagainya. Dalam Al-Qur'an, istilah bank tidak disebutkan secara eksplisit. Tetapi jika yang dimaksud adalah sesuatu yang memiliki unsur-unsur seperti struktur, manajemen, fungsi, hak dan kewajiban maka semua itu disebutkan dengan jelas, seperti zakat, sadaqah, ghanimah (rampasan perang), bai' (jual beli), dayn (utang dagang), maal (harta), dan sebagainya yang memiliki fungsi yang dilaksanakan oleh peran tertentu dalam kegiatan ekonomi. ${ }^{9}$

Istilah lain yang digunakan untuk sebutan bank Islam adalah bank syariah. Secara akademik, istilah Islam dan syariah memang mempunyai pengertian yang berbeda, namun secara teknisi untuk penyebutan bank Islam dan bank syariah mempunyai pengertian yang sama. Menurut Ensiklopedi Islam, bank Islam adalah lembaga keuangan yang usaha pokoknya memberikan kredit dan jasa dalam lalu lintas pembayaran serta peredaran uang yang pengoperasiannya disesuaikan dengan prinsip-prinsip syariat Islam. ${ }^{10}$

\section{b. Sejarah Bank Syariah}

Secara umum, bank adalah lembaga yang melaksanakan tiga fungsi utama, yaitu menerima simpanan uang, meminjamkan uang, dan memberikan jasa pengiriman uang. Di dalam sejarah perekonomian umat Islam, pembiayaan yang dilaksanakan dengan akad yang sesuai syariah telah menjadi bagian dari tradisi umat Islam sejak zaman Rasulullah SAW. Praktik-praktik seperti menerima titipan harta, meminjamkan uang untuk keperluan

\footnotetext{
${ }^{9}$ Heri Sudarsono, Bank dan Lembaga Keuangan Syariah, (Cet. II; Condongcatur: Ekonosia, 2004), h. 27.

${ }^{10}$ Risal Shetya, Analisis Kepuasan Nasabah di Bank Syariah Mandiri Palopo, dalam (Skripsi: Perpustakaan STAIN Palopo, 2010), h. 9.
} 
konsumsi dan untuk keperluan bisnis, serta melakukan pengiriman uang, telah lazim dilakukan sejak zaman Rasulullah SAW. Dengan demikian, fungsi-fungsi utama perbankan modern, yaitu menerima deposit, menyalurkan dana, dan melakukan transfer dana telah menjadi bagian yang terpisahkan dari kehidupan umat Islam, bahkan sejak zaman Rasulullah SAW.

Rasulullah SAW. yang dikenal dengan julukan al-amin, dipercaya oleh masyarakat Makkah menerima simpanan harta sehingga pada saat terakhir sebelum hijrah ke Madinah, ia meminta Ali bin Abi Thalib ra. untuk mengembalikan semua titipan itu kepada para pemiliknya. ${ }^{11}$

\section{c. Perbedaan bank syariah dengan bank konvensional}

\begin{tabular}{|c|c|c|c|}
\hline No & Bank Syariah & No & Bank Konvensional \\
\hline 1. & $\begin{array}{l}\text { Investasihanyauntukproyekdan } \\
\text { produk yang halal } \\
\text { danmenguntungkan. }\end{array}$ & 1. & $\begin{array}{ll}\text { Investasi, } \\
\text { tidakmempertimbangkan } & \text { halal } \\
\text { atau haram asalkanproyek yang } \\
\text { dibiayaimenguntungkan. }\end{array}$ \\
\hline 2. & $\begin{array}{l}\text { Return yang } \\
\text { dibayardanatauditerimaberasal } \\
\text { daribagihasilataupendapatanlai } \\
\text { nnyaberdasarkanprinsipsyariah }\end{array}$ & 2. & $\begin{array}{l}\text { Return baik yang } \\
\text { dibayarkepadanasbahpenyimpan } \\
\text { danadari return yang } \\
\text { diterimadarinasabahpenggunada } \\
\text { nberupabunga. }\end{array}$ \\
\hline 3. & $\begin{array}{l}\text { Perjanjian yang } \\
\text { dibuatdalambentukakadsesuaid } \\
\text { engansyariah Islam. }\end{array}$ & 3. & $\begin{array}{l}\text { Perjanjianmenggunakan hokum } \\
\text { positif. }\end{array}$ \\
\hline 4. & $\begin{array}{l}\text { Orientasipembiayaantidakhany } \\
\text { auntukkeuntunganakantetapiju } \\
\text { gafalahoriented,yaituberorienta } \\
\text { sipadakesejahteraanmasyarakat }\end{array}$ & 4. & $\begin{array}{l}\text { Orientasipembiayaanuntukmempe } \\
\text { rolehkeuntunganatasdana yang } \\
\text { dipinjamkan. }\end{array}$ \\
\hline 5. & $\begin{array}{ll}\text { Hubunganantara } & \text { bank } \\
\text { dannasabahadalahmitra. } & \end{array}$ & 5. & $\begin{array}{l}\text { Hubunganantara rank } \\
\text { dannasabahadalahkreditordandebi } \\
\text { tur. }\end{array}$ \\
\hline 6. & $\begin{array}{l}\text { Dewanpengawasterdiridari BI, } \\
\text { Bapepam, Komisaris, } \\
\text { danDewanpengawassyariah. }\end{array}$ & 6. & $\begin{array}{ll}\text { Dewanpengawasterdiridari } & \text { BI, } \\
\text { BapepamdanKomisaris. } & \end{array}$ \\
\hline 7. & $\begin{array}{l}\text { Penyelesaiansengketa, } \\
\text { diupayakandiselesaikansecarm } \\
\text { usyawaraantara bank } \\
\text { dannasabahmelaluipengadilan } \\
\text { agama. }\end{array}$ & 7. & $\begin{array}{l}\text { Penyelesaiansengketamelaluipeng } \\
\text { adilannegerisetempat. }\end{array}$ \\
\hline
\end{tabular}

\footnotetext{
${ }^{11}$ Adiwarman A. Karim, Bank Islam, (Ed; II. Jakarta: Grafindo Persada, 2004), h. 18.
} 


\section{B. Kerangka Pikir}

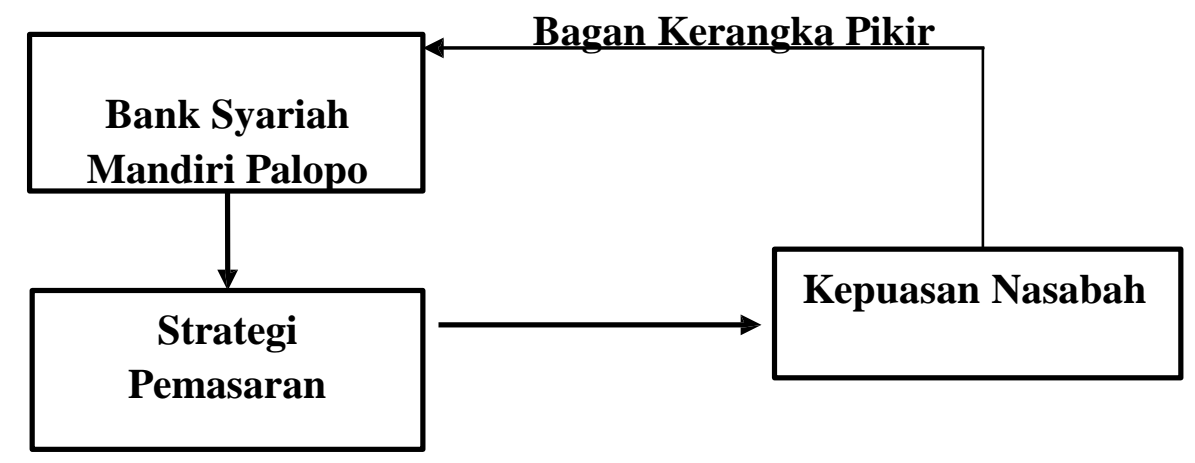

${ }^{12}$ Abdul Rahmat, Pengaruh Produk Gadai Emas Terhadap Kepuasan Nasabah di Bank Syariah Mandiri, op. cit., h. 50. 


\section{METODE PENELITIAN}

\section{A. Pendekatan dan jenis penelitian}

Pendekatan yang digunakan dalam penelitian ini, yaitu penelitian kuantitatif. Penelitian kuantitatif merupakan suatu penelitian yang analisisnya secara umum memakai analisis statistik. Karenanya dalam penelitian kuantitatif pengukuran terhadap gejala yang diminati menjadi penting, sehingga pengumpulan data dilakukan dengan menggunakan daftar pertanyaan berstruktur (angket) yang disusun berdasarkan pengukuran terhadap variabel yang diteliti yang kemudian menghasilkan data kuantitatif. Berdasarkan hal di atas, untuk memperoleh hasil penelitian yang lebih sistematis dan terarah, maka penelitian ini disusun melalui penyebaran angket dan pengelolaan data yang menyangkut pengklasifikasian data dan penyusunan hasil penelitian yang selanjutnya dideskripsikan sebagai hasil penelitian.

\section{B. Lokasi Penelitian}

Penelitian ini dilakukan terhadap nasabah Bank Syariah Mandiri cabang Palopo dengan maksud penelitian untuk mengetahui strategi pemasaran terhadap kepuasan menjadi nasabah bank syariah. Adapun lokasi ini dipilih karena akan memudahkan peneliti melakukan penelitian pada Bank Syariah Mandiri cabang Palopo.

\section{Sumber Data}

\section{Data Primer}

Adalah data yang diperoleh peneliti dari sumber pertama, seperti wawancara atau hasil pengisian kuisioner. ${ }^{12}$ Oleh nasabah Bank Syariah Mandiri cabang Palopo.

\section{Data Sekunder}

Adalah data yang diperoleh dari pihak tertentu yang sangat berhubungan dengan penelitian. Data diperoleh dengan cara:

a. Pencatatan, yaitu dengan mencatat dari laporan-laporan yang mendukung penelitian.

b. Studi Kepustakaan, yaitu metode pengumpulan data dengan membaca referensi yang berhubungan dengan objek penelitian.

c. Literatur, yaitu dari internet dan buku-buku yang dianggap relevan terutama dalam hal menunjang tinjauan teoritis terhadap penulisan skripsi ini.

\section{Variabel Penelitian}

Skripsi ini berjudul Strategi Pemasaran Terhadap Kepuasan Menjadi Nasabah Bank Syariah Mandiri Cabang Palopo. Untuk memudahkan dalam analisis data peneliti membagi variabel menjadi dua yaitu:

1. Variabel bebas $(\mathrm{X})$, yaitu strategi pemasaran

2. Variabel dependen (Y) Kepuasan Nasabah. 


\section{E. Populasi}

Populasi adalah wilayah generalisasi yang terdiri atas, objek atau subjek yang mempunyai kualitas dan karakteristik tertentu yang diterapkan oleh peneliti untuk dipelajari dan kemudian disimpulkan. ${ }^{13}$ Adapun populasi dalam penelitian ini adalah nasabah Bank Syariah Mandiri cabang Palopo Kota Palopo tahun 2015 yang berjumlah 3600 nasabah. ${ }^{14}$

\section{F. Sampel}

Sampel adalah bagian dari jumlah dan karakteristik yang dimiliki oleh populasi tersebut. ${ }^{15}$ Jika populasinya kurang dari 100 maka lebih baik semua dijadikan sebagai sampel. Tetapi jika jumlah populasi cukup besar atau diatas 100 maka dapat diambil 10$15 \%$ atau $15-20 \%$. Dikarenakan jumlah populasi pada penelitian ini cukup besar maka peneliti menggunakan sampel dengan teknik sampel acak, untuk menentukan jumlah populasi peneliti menggunakan rumus slovin sebagai berikut:

$$
\mathrm{n}=\frac{\mathrm{N}}{1+\mathrm{Ne}^{2}}
$$

Keterangan :

$\mathrm{n}=$ Ukuran Sampel

${ }^{13}$ Sugiyono, Metode Penelitian Manajemen, (cet. I, Bandung: Alfabeta, 2013), h. 148.

${ }^{14}$ Faisal Podo, Pengaruh Layanan Terhadap Loyalitas Nasabah Bank Syariah Mandiri Palopo, Skripsi (Palopo: IAIN Palopo, 2016), h.27.

${ }^{15}$ Sugiyono, Statistik untuk Penelitian, (cet. XXI, Bandung: Alfabeta, 2012), h. 18. 
$\mathrm{N}=$ Jumlah Populasi

$\mathrm{e}=$ Kesalahan pengambilan sampel yang masi di tolelir yaitu $(0,1)$ atau $10 \%$.

$$
\begin{aligned}
n & =\frac{3600}{3600(0.1)^{2}} \\
& =97.29
\end{aligned}
$$

Berdasarkan perhitungan maka diperoleh jumlah sampel sebanyak 97.29 dan dibulatkan menjadi 97 sampel atau responden.

\section{G. Teknik Pengumpulan Data}

Dalam pengumpulan data yang relevan dengan penelitian ini, penulis menggunakan dua metode yaitu sebagai berikut:

\section{Field Research}

Pengumpulan data yang berkaitan dengan judul skripsi ini langsung dari lokasi penelitian. Pada teknik ini digunakan beberapa instrumen sebagai berikut:

a. Angket (kuesioner), yaitu dengan mengajukan pertanyaan-pertanyaan tersusun secara kronologis dari yang umum mengarah kepada yang khusus untuk diberikan kepada responden dalam bentuk tertulis (daftar pertanyaan).

b. Observasi, yaitu metode pengumpulan data dengan cara menggunakan pengamatan langsung di lapangan dengan mengenal dan mengetahui objek yang akan diteliti dalam peneliti ini penulis melakukan pengamatan langsung pada nasabah Bank Syariah Cabang Palopo.

c. Dokumentasi, Dokumentasi berasal dari kata "dokumen" yang artinya barang-barang tertulis catatan seperti catatan, transkip, buku-buku, surat kabar, notulen rapat, agenda dan lain sebagainya. Teknik dokumentasi berarti cara mengumpulkan data dengan mancatat data-data yang sudah ada. ${ }^{16}$ Berdasarkan pengertian dari dokumentasi dapat dipahami bahwa dokumen merupakan data-data yang telah lalu, baik yang dinyatakan dalam bentuk tulisan, lisan ataupun gambaran yang berkaitan dengan penelitian ini. Dokumen bisa berbentuk tulisan, gambar, atau karya-karya monumental dari seseorang.

\section{Library Reseach}

Metode pengumpulan data yang dilakukan dengan cara membaca buku-buku yang merujuk dengan pembahasan skripsi ini penulis menggunakan teknik pengutipan sebagai berikut:

a. Kutipan langsung, yaitu mengutip tanpa mengubah redaksi teks yang dikutip sebagaimana dengan teks lainnya.

\footnotetext{
${ }^{16}$ Amirul Hadi Haryono, Metodologi Penelitian Pendidikan II, (Bandung: Pustaka Setia, 1998), h. 83.
} 
b. Kutipan tidak langsung, yaitu mengutip dengan hanya mengambil intisari atau makna dari teks yang dikutip tanpa mengikuti redaksi aslinya.

\section{H. Teknik Pengolahan dan Analisis Data}

Menurut Bogdan, ${ }^{17}$ analisis data merupakan proses lanjutan setelah data yang dibutuhkan telah terkumpul. Data-data yang telah dikumpulkan tersebut masih bersifat mentah sehingga butuh proses lanjutan berupa pengelolaan data yang kemudian dianalisis untuk menjawab peryataan-pernyataan penelitian yang telah dikemukakan sebelumnya. Adapun uji dan analisis yang digunakan pada penelitian ini sebagai berikut:

1. Uji Validitas

Ini digunakan untuk mengetahui kevalidan atau kesesuaian angket yang peneliti gunakan memperoleh data dari responden, uji validitas data menngunakan prinsip mengkorelasikan atau menghubungkan antara masing-masing akor item dengan skor total yang diperoleh dalam penelitian.

2. Realibitas

Uji ini berfungsi untuk mengetahui tingkat kekonsistensian angket yang digunakan oleh peneliti sehingga angket tersebut dapat diandalkan.

3. Uji Normalitas data

Uji Normalitas data ini bertujuan untuk menguji data penelitian apakah berdistribusi normal atau tidak.

4. Uji t

Uji tadalah jenis pengujian statistika untuk mengetahui apakah ada perbedaan dari nilai yang diperkirakan dengan nilai hasil perhitungan statistika. Uji t pada dasarnya menunjukkan seberapa jauh pengaruh satu variabel bebas secara individual dalam menerangkan variasi variabel terikat.Uji t menilai apakah mean dan keragaman dari dua kelompok berbeda secara statistik satu sama lain. Analisis ini digunakan untuk menguji hipotesis.

a. Jika Kai Kuadrat observasi Thitung, sama atau lebih besar daripada harga kritik Kai kudrat yang tercantum dalam tabel Ttabel, maka Hipotesa Alternatif (H0) di tolak atau H1 dierima, artinya ada pengaruh dari faktor yang diselidiki. Adanya perbedaan tersebut mengandung makna bahwa ada pengaruh yang signifikan pada faktor yang kita selidiki.

\footnotetext{
${ }^{17}$ Adnan Mahdi dan Mujahidin, Panduan Penelitian Praktis Untuk Menyusun Skripsi, Tesis, \& Disertasi, (Bandung: Alfabeta, 2014), h. 133.
} 
b. Jika Kai Kuadrat observasi Thitung, lebih kecil daripada harga kritik Kai kudrat yang tercantum dalam tabel Ttabel, maka Hipotesa Alternatif (H0) di terima atau H1 ditolak, artinya dalam hipotesis tersebut tidak ada pengaruh dari faktor yang diselidiki, maka tidak ada pengaruh yang signifikan pada faktor yang kita selidiki. ${ }^{18}$

\section{Koefisien Determinasi}

Setelah diketahui apakah terdapat pengaruh atau tidak pada variabel yang diteliti, untuk melihat seberapa besar pengaruh yang ditimbulkan variabel $\mathrm{X}$ terhadap variabel $\mathrm{Y}$, dapat dilihat pada R square yang kemudian di kalkulasikan dengan 100\%.

\section{Persamaan Regresi Linier Sederhana}

Dalam melakukan analisis data dari butir-butir kuesioner yang digunakan untuk menentukan kategori pengaruh strategi pemasaran terhadap kepuasan nasabah adalah skala likert yang dikembangkan dan membuat sejumlah pertanyaan yang mengacu pada lima alternatif jawaban yaitu: sangat setuju (SS), setuju (S), ragu-ragu (RR), tidak setuju (TS) dan sangat tidak setuju (STS). Pemberian bobot untuk setiap pertanyaan positif dimulai dari 5,4,3,2,1, sedangkan yang negatif dimulai dari 1,2,3,4,5. Dengan menggunakan SPSS (Statistical Product and Service) ver. 20.0 for windows sebagai alat analisis. ${ }^{19}$ Dari hasil data tersebut, selanjutnya dianalisis secara deskriptif yang bersifat kuantitatif yaitu untuk melihat strategi pemasaran terhadap kepuasan menjadi nasabah bank syariah. Untuk menentukan hasil dari analisis data tersebut peneliti menggunakan analisis data regresi linear sederhana dengan menggunakan rumus sebagai berikut:

$$
\begin{aligned}
& =+ \\
& Y=\text { variabel kepuasan nasabah } \\
& \alpha=\text { Konstanta } \\
& \mathrm{b}=\text { Koefesien regresi } \\
& \mathrm{X}=\text { Variabel Strategi pemasaran }
\end{aligned}
$$

\section{HASIL PENELITIAN}

\section{A. Hasil Penelitian}

1. Deskriptif Karakteristik Responden

Deskripsi karakteristik responden adalah menguraikan atau memberikan gambaran mengenai identitas responden, disajikan dalam bentuk tabel yang dinyatakan

\footnotetext{
Syofian Siregar, Statıstık Parametrik Untuk Penelitian Kuantitatif, (Ed.1, Cet.2; Jakarta: Bumi Aksara, 2014), h. 194.

${ }^{19}$ Hartono, Statistik Untuk Penelitian, (Cet. VI; Yogyakarta: Pustaka Pelajar, 2012), h. 157.
} 
dalam presentase, maka akan dapat di ketahui sejauh mana identitas responden dalam penelitian ini. Pembahasan dalam penelitian ini bertujuan untuk mengetahui pengaruh strategi pemasaran dan kepuasan nasabah di Bank Syariah Mandiri Palopo dimana ditetapkan sebesar 50 orang nasabah. Dalam pelaksanaan penelitian ini, ditetapkan sebesar 50 orang responden, dimana dari 50 kuesioner yang dibagikan kepada responden telah dikembalikan dan semuanya dapat diolah lebih lanjut. Oleh karena itu akan disajikan deskripsi identitas responden yang dapat diuraikan sebagai berikut:

Tabel 4.1

Karakteristik Responden Menurut Umur

\begin{tabular}{|l|l|l|l|}
\hline No & Kelompok Umur (Tahun) & & Jumlah \\
& & & Presentase (\%) \\
\hline 1 & $20-35$ & 28 & $56 \%$ \\
\hline 2 & $36-45$ & 13 & $26 \%$ \\
\hline 3 & $46-50$ & 7 & $14 \%$ \\
\hline 4 & $>50$ & 2 & $4 \%$ \\
\hline \multicolumn{2}{|l|}{ Total } & 50 & $100 \%$ \\
\hline
\end{tabular}

Sumber: Hasil Pengolahan Data Primer (Kuesioner), 2016

Dari tabel 4.1 tersebut, menunjukkan bahwa kelompok umur 20-35 tahun adalah kelompok umur yang dominan jumlahnya, karena terdapat 28 responden (56\%), sedangkan kelompok umur yang terkecil jumlahnya adalah kelompok umur lebih dari 50 tahun, dimana hanya berjumlah 2 responden (4\%). Umur termudah dalam penelitian ini adalah 20 tahun dan yang tertua adalah 52 tahun. Dan kelompok umur 35-45 tahun jumlahnya 13 responden (26\%). Sedangkan umur 46-50 berjumlah 7 responden (14\%). Sehingga dapat disimpulkan bahwa rata-rata nasabah yang ada di Bank Syariah Mandiri Palopo mempunyai umur antara 20-35 tahun.

\section{Uji Validitas dan Reliabilitas}

a. Uji Validitas

Uji validitas yaitu analisis untuk mengukur valid atau tidaknya butir-butir pertanyaan atau pernyataan yang ada pada angket, dan kemudian diuji terhadap faktor terkait dengan membandingkan nilai rtabel dan rhitung atau total korelasi. Pada penelitian ini peneliti mengambil 97 sampel atau $\mathrm{N}$, untuk mengetahui data tersebut valid atau tidak, terlebih dahulu tentukan nilai rtabel yang telah ada.Jadi $\mathrm{df}=97$ peneliti menggunaka tingkat kepercayaan sebesar 95\%, 100\%-95\% = 5\% atau signifikasi 0.05 sehingga didapat nilai rtabel pada 97 sampel adalah 0.196. Adapun dasar pengambilan keputusan data dikatakan valid atau tidak valid adalah:

Apabila nilai rhitung > rtabel maka data valid 
Apabila nilai rhitung < rtabel maka data tidak valid.

Tabel 4.3

Uji Validitas Variabel X (Strategi Pemasaran)

\begin{tabular}{|c|c|c|c|}
\hline Variabel & Pertanyaan & Nilai $R_{\text {hitung }}$ & Keterangan \\
\hline \multirow{7}{*}{$\begin{array}{c}\text { Strategi } \\
\text { pemasaran } \\
(\mathrm{X})\end{array}$} & P1 & 0.415 & Valid \\
\hline & $\mathrm{P} 2$ & 0.595 & Valid \\
\hline & P3 & 0.438 & Valid \\
\hline & $\mathrm{P} 4$ & 0.540 & Valid \\
\hline & P5 & 0.218 & Valid \\
\hline & P6 & 0.345 & Valid \\
\hline & P7 & 0.547 & Valid \\
\hline
\end{tabular}

Tabel 4.4

Uji Validitas Variabel Y (Kepuasan Nasabah)

\begin{tabular}{|c|c|c|c|}
\hline Variabel & Pertanyaan & Nilai $R_{\text {hitung }}$ & Keteranan \\
\hline \multirow{16}{*}{$\begin{array}{c}\text { Kepuasan } \\
\text { Nasabah } \\
\text { (Y) }\end{array}$} & P8 & 0.396 & Valid \\
\hline & P9 & 0.467 & Valid \\
\hline & $\mathrm{P} 10$ & 0.478 & Valid \\
\hline & $\mathrm{P} 11$ & 0.402 & Valid \\
\hline & $\mathrm{P} 12$ & 0.302 & Valid \\
\hline & $\mathrm{P} 13$ & 0.121 & Tidak Valid \\
\hline & $\mathrm{P} 14$ & 0.328 & Valid \\
\hline & P15 & 0.336 & Valid \\
\hline & $\mathrm{P} 16$ & 0.613 & Valid \\
\hline & $\mathrm{P} 17$ & 0.549 & Valid \\
\hline & $\mathrm{P} 18$ & 0.453 & Valid \\
\hline & $\mathrm{P} 19$ & 0.330 & Valid \\
\hline & $\mathrm{P} 20$ & 0.299 & Valid \\
\hline & $\mathrm{P} 21$ & 0.418 & Vaid \\
\hline & $\mathrm{P} 22$ & 0.678 & Valid \\
\hline & $\mathrm{P} 23$ & 0.288 & Valid \\
\hline
\end{tabular}

Dari hasil uji Validitas, terdapat satu pertanyaan yang tidak valid yaitu pertanyaan ke tiga belas, sehingga peneliti harus mengeluarkan pertanyaan yang tidak valid tersebut, selain itu semua pernyataan dinyatakan valid dan menyisahkan 22 pertanyaan yang selanjutnya diuji reliabilitasnya.

b. Uji Reliabilitas

Uji reliabilitas menunjukan hasil pengukuran yang dapat dipercaya. Ada beberapa teknik yang dapat digunakan untuk mengukur reliabilitas suatu instrumen penelitian, 
tergantung dari skala yang digunakan. Salah satunya reliabilitas item diuji dengan melihat koefisien alpha dengan melakukan reliability analisis dengan SPSS (Statistical Product and Service) ver. 20.0 for windows. Akan dilihat nilai alpha-cronbach untuk reliabilitas keseluruhan item dalam satu variabel. Agar lebih teliti, dengan menggunakan SPSS, juga akan dilihat kolom corrected item total correlation. Dan kemudian dibandingkan dengan nilai rtabel telah didapat nilai rtabel pada sampel 97 adalah 0.196. Adapun dasar pengambilan keputusan data reliabel atau tidak adalah:

Apabila nilai alpha > rtabel maka data reliabel

Apabila nilai alpha < rtabel maka data tidak reliabel tabel berikut:

Berikut hasil uji dari pengujian reliabilitas setiap variabel, dapat dilihat pada

Tabel 4.4

Uji Reliabilitas Variabel X (Strategi Pemasaran)

Sumber: Data diolah SPSS 2016.

\begin{tabular}{|l|l|l|l|}
\hline Variabel & Pertanyaan & Nilai Alpha & Keterangan \\
\hline \multirow{5}{*}{ Strategi Pemasaran $(\mathbf{X})$} & P1 & 0.638 & Reliabel \\
\cline { 2 - 4 } & P2 & 0.602 & Reliabel \\
\cline { 2 - 4 } & P3 & 0.635 & Reliabel \\
\cline { 2 - 4 } & P4 & 0.616 & Reliabel \\
\cline { 2 - 4 } & P5 & 0.678 & Reliabel \\
\cline { 2 - 4 } & P6 & 0.652 & Reliabel \\
\cline { 2 - 4 } & P7 & 0.608 & Reliabel \\
\hline
\end{tabular}

Dari hasil uji SPSS semua pernyataan dinyatakan reliabel.

Tabel 4.

Uji Reliabilitas Variabel Y (Kepuasan Nasabah)

\begin{tabular}{|l|l|l|l|}
\hline Variabel & Pertanyaan & Nilai Alpha & Keterangan \\
\hline \multirow{5}{*}{ Kepuasan Nasabah (Y) } & P8 & 0,687 & Reliabel \\
\cline { 2 - 4 } & P9 & 0,681 & Reliabel \\
\cline { 2 - 4 } & P310 & 0,679 & Reliabel \\
\cline { 2 - 4 } & P11 & 0,689 & Reliabel \\
\cline { 2 - 4 } & P12 & 0,693 & Reliabel \\
\cline { 2 - 4 } & P14 & 0,695 & Reliabel \\
\cline { 2 - 4 } & P15 & 0,688 & Reliabel \\
\cline { 2 - 4 } & P16 & 0,673 & Reliabel \\
\cline { 2 - 4 } & P17 & 0,674 & Reliabel \\
\cline { 2 - 4 } & P18 & 0,684 & Reliabel \\
\cline { 2 - 4 } & P19 & 0,692 & Reliabel \\
\cline { 2 - 4 } & P20 & 0,693 & Reliabel \\
\cline { 2 - 4 } & P21 & 0,688 & Reliabel \\
\cline { 2 - 4 } & P22 & 0,668 & Reliabel \\
\cline { 2 - 4 } & P23 & 0,694 & Reliabel \\
\hline
\end{tabular}

Sumber: Data diolah SPSS 2016. 
Dari hasil uji SPSS semua pernyataan dinyatakan reliabel.

\section{Uji Normalitas}

Uji normalitas adalah untuk melihat apakah nilai residual terdistribusi normal atau tidak. Model regresi yang baik adalah memiliki nilai residual yang terdistribusi normal.. Adapun dasar pengambilan keputusan data dinyatakan terdistribusi normal atau tidak normal adalah sebagai berikut :

Nilai sig residual $>0,05$ maka data terdistribusi noramal

Nilai sig residual $<0,05$ maka data terdistribusi tiadak normal

Berikut hasil uji dari pengujian normalitas dapat dilihat pada tabel dibawah

Tabel 4.5

Output SPSS Uji Normalitas

One-Sample Kolmogorov-Smirnov Test

\begin{tabular}{|ll|r|}
\hline \multirow{2}{*}{$\mathrm{N}$} & & $\begin{array}{c}\text { Unstandardized } \\
\text { Residual }\end{array}$ \\
\cline { 3 - 3 } Normal Parameters ${ }^{\mathrm{a}, \mathrm{b}}$ & Mean & 50 \\
& Std. Deviation & $0 \mathrm{E}-7$ \\
Most Extreme Differences & Absolute & 4,50079248 \\
& Positive &, 141 \\
Kolmogorov-Smirnov Z & Negative &, 080 \\
Asymp. Sig. (2-tailed) & &,- 141 \\
a. Test distribution is Normal. &, 997 \\
\hline
\end{tabular}

Dari hasil analisis data uji normalitas instrumen di dapat nilai sig residual pada penelitian ini adalah $0.274>0.05$ maka data tersebut terdistribusi normal. Dapat dilihat pula secara visual dengan P-plot pada gambar berikut:

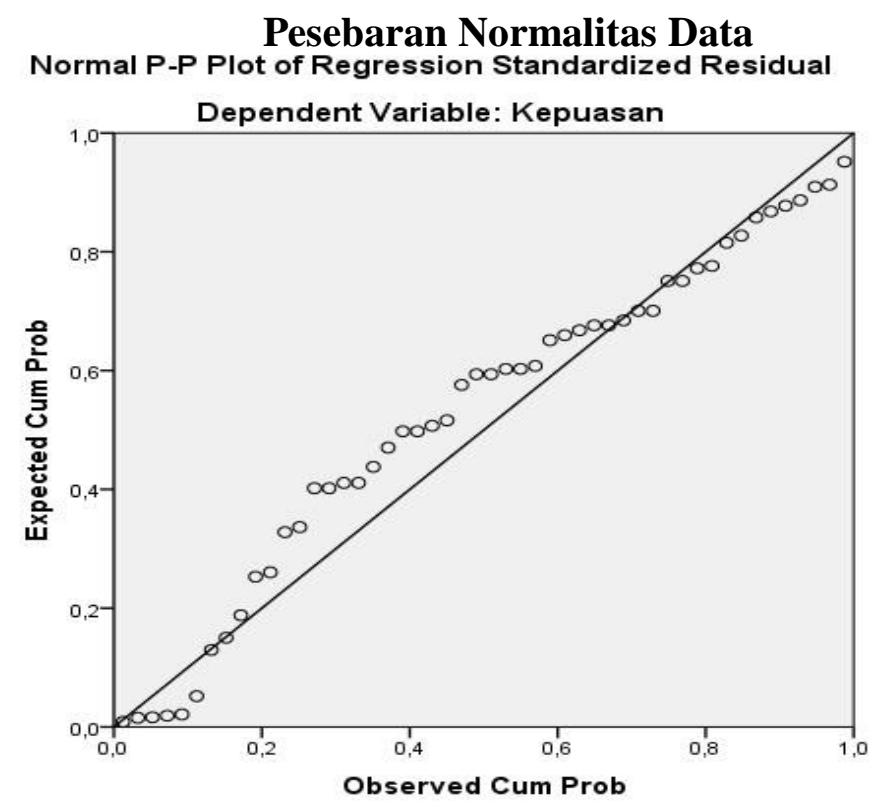

Sumber : Data diolah SPSS 2016.

\section{P engujian Hipotesis}


Adapun alternatif hipotesis pada penelitian ini adalah:

$\mathrm{H}_{0}=$ Tidak terdapat pengaruh yang signifikan pada strategi pemasaran terhadap kepuasan nasabah.

$\mathrm{H}_{1}=$ Terdapat pengaruh yang signifikan pada strategi pemasaran terhadap kepuasan nasabah.

Setelah diuji validitas, reliabilitas dan normalitas maka instrument yang dinyatakan valid, relibel dan terdistribusi normal, selanjutnya dapat digunakan dalam pengujian hipotesis. Adapun hasil uji tersebut sebagai berikut:

a. Uji t

Uji t bertujuan untuk mengetahui apakah variabel independen secara parsial berpengaruh signifikan terhadap variabel dependen. Adapun dasar pengambilan keputusan untuk pengujian $\mathrm{t}$ dalam analisis ini adalah sebagai berikut:

Jika nilai Thitung > Ttabel maka variabel bebas berpengaruh terhadap variabel terikat

Jika nilai Thitung < Ttabel maka variabel bebas tidak berpengaruh terhadap variabel terikat.

Nilai $\mathrm{T}_{\text {tabel }}$ dalam penelitian ini adalah 1.660. Sedangkan untuk mencari nilai $\mathrm{T}_{\text {hitung, didapat }}$ melalui pengujian dengan bantuan SPSS 22.00 diperoleh hasil sebagai berikut:

Tabel 4.5

Output SPSS Uji t

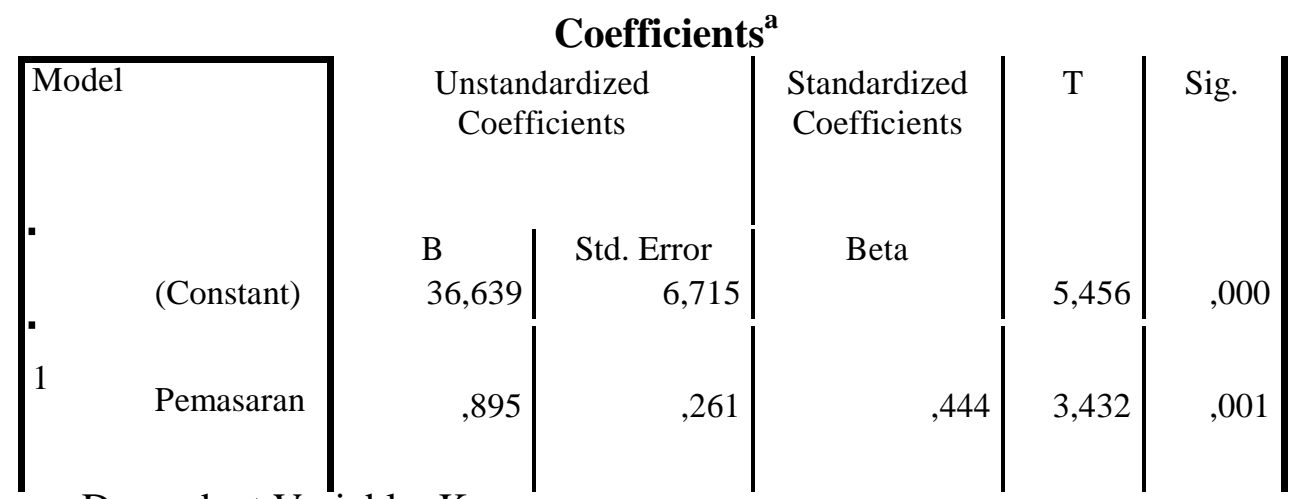

a. Dependent Variable: Kepuasan

Sumber: Data diolah SPSS 2016

Dari hasil analisis data uji $t$ dengan menggunakan SPSS diketahui besarnya $T_{\text {hitung }}$ sebagai berikut:

Variabel strategi pemasaran $X(3.432)>$ nilai $T_{\text {tabel }}(1.660)$, sehingga diperoleh hasil terdapat pengaruh variabel $\mathrm{X}$ (strategi pemasaran) terhadap variabel $\mathrm{Y}$ (kepuasan nasabah). Sehingga diperoleh hasil $\mathrm{H}_{0}$ ditolak artinya terdapat pengaruh yang signifikan antara strategi pemasaran terhadap kepuasan nasabah.

b. Uji Regresi Linear Sederhana 
Tabel 4.6

Output Persamaan Regresi Sederhana Coefficients $^{\mathrm{a}}$

\begin{tabular}{|c|c|c|c|c|c|c|}
\hline \multirow{2}{*}{\multicolumn{2}{|c|}{ Model }} & \multicolumn{2}{|c|}{ Unstandardized Coefficients } & \multirow{2}{*}{$\begin{array}{c}\text { Standardized } \\
\text { Coefficients } \\
\text { Beta } \\
\end{array}$} & \multirow[b]{2}{*}{$t$} & \multirow[b]{2}{*}{ Sig. } \\
\hline & & B & Std. Error & & & \\
\hline \multirow[t]{2}{*}{1} & (Constant) & 36,639 & 6,715 & & 5,456 &, 000 \\
\hline & Pemasaran &, 895 &, 261 & 444 & 3,432 & 001 \\
\hline
\end{tabular}

a. Dependent Variable: Kepuasan

Sumber: Data diolah SPSS, 2016

Berdasarkan tabel diatas maka nilai yang ada dapat diinterpretasikan sebagai berikut:

$\mathrm{Y}: \mathrm{a}+\mathrm{bx}$

$\mathrm{Y}: 36.639+0.895 \mathrm{x}$

Persamaan regresi linier variabel strategi pemasaran terhadap kepuasan adalah sebagai berikut:

Kepuasan Nasabah pada Bank Syariah Mandiri sebelum adanya peningkatan strategi pemasaran adalah sebesar 36.639. ketika strategi pemasaran ditingkatkan 1 poin maka kepuasan nasabah bertambah sebesar 0.895 .

\section{Koefisien Determinasi}

Untuk mengetahui besarnya pengaruh yang ditimbulkan dapat dilihat dengan $\mathrm{R}$ square $\left(\mathrm{R}^{2}\right)$ atau kuadrat dari $\mathrm{R}$, yaitu menunjukkan koefisien determinansi.

Nilai yang akan didapatkan diubah kebentuk persen, yang artinya persentase sumbangan pengaruh variabel independen terhadap variabel dependent.

Tabel 4.7

Output Uji Koefisien Determinasi

Model Summary

\begin{tabular}{|l|l|r|r|r|}
\hline Model & $\mathrm{R}$ & R Square & $\begin{array}{c}\text { Adjusted R } \\
\text { Square }\end{array}$ & $\begin{array}{c}\text { Std. Error of } \\
\text { the Estimate }\end{array}$ \\
\hline 1 &, $444^{\text {a }}$ &, 197 &, 180 & 4,547 \\
\hline
\end{tabular}

a. Predictors: (Constant), Pemasaran

b. Dependent Variable: Kepuasan

Sumber: Data diolah SPSS 2016

Nilai $\mathrm{R}^{2}$ yang didapatkan dari hasil pengolahan sebesar 0.197 artinya sumbangan presentase pengaruh variabel independen sebesar $19.7 \%$. Sisanya $100 \%-19,7 \%=80.3 \%$ dipengaruhi oleh variabel lain yang belum dimasukkan dalam model. Sehingga diperoleh hasil pengaruh yang ditimbulkan strategi pemasaran terhadap kepuasan nasabah sebesar $19.7 \%$. 


\section{B. Pembahasan Hasil Penelitian}

Dari hasil analisis di atas diperoleh persamaan regresi yaitu $\mathrm{Y}=36.639+0.895$. Berdasarkan pengujian hipotesis diperoleh nilai $\mathrm{T}_{\text {hitung }}=3.432$ dan nilai $\mathrm{T}_{\text {tabel }}=1.660$, diambil keputusan bahwa $\mathrm{H}_{0}$ ditolak karena $\mathrm{T}_{\text {hitung }}>\mathrm{T}_{\text {tabel }}$ artinya ada pengaruh yang signifikan antara pengaruh strategi pemasaran terhadap kepuasan nasabah Bank Syariah Mandiri. Jadi persamaan regresi tersebut dapat digunakan untuk meramalkan besarnya variabel terikat $(\mathrm{Y})$ berdasarkan variabel bebas $(\mathrm{X})$. Kemudian diuji apakah memang valid untuk memprediksi variabel terikatnya. Artinya apakah strategi pemasaran berpengaruh terhadapa kepuasan nasabah. Sehingga persamaan regresi dapat dijelaskan sebagai berikut:

1. Nilai konstanta $a=36.639$ merupakan nilai dari kepuasan nasabah.

2. Koefisien regresi sebesar 0.895 bertanda positif menyatakan bahwa setiap penambahan nilai sebesar 1 poin untuk strategi pemasaran akan meningkatkan kepuasan nasabah sebesar 0.895. Dan sebaliknya jika nilai strategi pemassaran turun 1 poin maka nilai dari kepuasan nasabah akan turun sebesar 0.895 poin. Dari persamaan terlihat bahwa koefisien $\mathrm{b}$ bernilai positif, ini menunjukkan bahwa perubahan $\mathrm{Y}$ searah dengan perubahan $\mathrm{X}$. Jadi nilai $\mathrm{Y}$ akan meningkat jika $\mathrm{X}$ meningkat, sebaliknya nilai $\mathrm{Y}$ akan menurun jika $\mathrm{X}$ menurun.

Startegi pemasaran merupakan suatu cara yang digunakan untuk menarik nasabah. Strategi pemasaran atau marketing dalam Bank hal yang penting untuk menambah nasabah. Pelayanan yang baik terhadap nasabah merupakan salah satu strategi untuk memuaskan nasabah dalam bertransaksi ataupun melakukan komunikasi terhadap pihak Bank. Tingkat kepuasan nasabah nerupakan hal pokok yang harus diutamakan oleh pihak Bank untuk menarik nasabah yang lain.

Untuk meningkatkan suatu penjualan atau produk dalam dunia bisnis maka pihak dari Bank harus menetapkan fungsi dan strategi pemasaran yang lebih matang agar tingkat penjualan sebuah produk lebih meningkat.

\section{KESIMPULAN}

Berdasarkan uraian yang telah dikemukakan dapat diambil kesimpulan sebagai berikut:

1. Hasil penelitian menunjukkan bahwa variabel strategi pemasaran (X) mempunyai pengaruh yang positif dan signifikan terhadap kepuasan nasabah (Y). Hal ini 
ditunjukkan pada hasil uji t dimana variabel strategi pemasaran $(\mathrm{X})$ mempunyai nilai $\mathrm{T}_{\text {hitung }}$ (3.432) dan nilai $\mathrm{T}_{\text {tabel }}$ (1.660). Dengan demikian $\mathrm{H}_{1}$ diterima artinya ada hubungan yang linear antara pengaruh strategi pemasaran terhadap terhadap kepuasan nasabah, dan $\mathrm{H}_{0}$ ditolak artinya tidak ada hubungan yang linear antara pengaruh strategi pemasaran terhadap kepuasan nasabah.

2. Besar pengaruh yang di timbulkan strategi pemasaran terhadap kepuasan nasabah di Bank Syariah Mandiri Cabang Palopo 0.895. Kepuasan Nasabah pada Bank Syariah Mandiri sebelum adanya peningkatan strategi pemasaran adalah sebesar 36.639 ketika startegi pemasaran di tingkatkan 1 poin maka kepuasan bertambah 0.895 .

\section{B. Saran-saran}

1. Strategi pemasaran merupakan hal yang sangat penting bagi nasabah pada Bank Syariah Mandiri Cabang Palopo dalam meningkatkan kepuasan nasabah. Untuk itu bagi pihak Bank Syariah Mandiri Cabang Palopo kiranya memperhatikan strategi pemasaran yang digunakan untuk memenuhi kepuasan nasabah.

2. Bagi peneliti selanjutnya di harapkan dapat meneliti deengan variabel lain lagi agar memperoleh hasil yang bervariatif yang dapat berguna bagi pihak Bank Syariah Mandiri Cabang Palopo dan nasabahnya. 